\title{
Quilts: Unfolding personal and public histories in South Africa and the United States
}

$>\quad$ Marsha MacDowell

Michigan State University Museum, East Lansing, Michigan, United States of America.

macdowel@msu.edu (ORCID: https://orcid.org/0000-0003-3614-6514)

\begin{abstract}
Quilts and related textiles are a particularly capacious textile medium through which the intersection of materiality and narratives can be explored. There are thousands of extant historical examples to be found in public and private collections, and the "quilt world" of the early twenty-first century is robust and enormous. There are literally millions of individuals around the globe who are involved in some aspect of quilt production, preservation, and study. This article provides a brief overview of quiltmaking and quilt studies in the United States and in South Africa. It draws upon samples of work from both countries to illustrate how, through their needles and their stories, quilt artists provide unique windows into personal and public histories.
\end{abstract}

Keywords: South Africa, textiles, quilts, history, material culture.

Published by

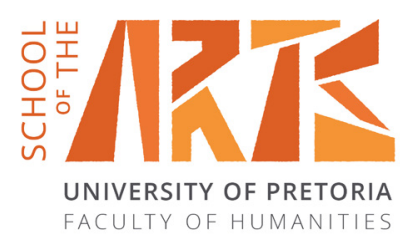




\section{Introduction}

Quilts and related textiles are a particularly capacious textile medium through which the intersection of materiality and narratives can be explored. There are thousands of extant historical examples to be found in public and private collections, and the "quilt world" of the early twenty-first century is robust and enormous. There are literally millions of individuals around the globe who are involved in some aspect of quilt production, preservation, and study. In this article I provide a brief overview of quiltmaking and quilt studies in the United States and in South Africa. I then draw upon samples of work from both countries to illustrate how, through their needles and their stories, quilt artists provide unique windows into personal and public histories. ${ }^{1}$

\section{Reading women's history through quilts}

Material objects are critical to our understanding of humankind; studies of cloth, one of the oldest and most fundamental aspects of our material world, are key to investigating the development of civilisation (see Barber 1994; Livingstone \& Ploof 2007; Weiner \& Schneider 1989; Gordon 2019). The study of textiles was historically hampered by several factors. First, as an often perishable material object, textiles of ancient times simply no longer exist, except as depicted in other art forms or as fragments found in archaeological excavations. Second, the production of textiles is overwhelmingly considered women's work and situated in domestic life, realms that were of little interest for interrogation by scholars until the rise of feminist studies in the latter part of the twentieth century. Feminist art historian Rozsika Parker, in the foreword to her influential book The Subversive Stitch on one such domestic art - embroidery - stated simply how essential the investigation of textiles is to understanding women's lives, 'to know the history of embroidery is to know the history of women' (Parker 1984:[sp]). Within the context of studies of material culture, especially that of women, the examination of the intersection of narratives and cloth offers special opportunities to illuminate history. As Maureen Daly Goggin (2009:1), suggests, a scholar who specialises in theorising and historicising praxis of material culture, a focus on women and material culture, particularly on textiles, enables us to understand 'just how deeply the needle has pierced social, political, economic, ethnic, and cultural facets of humanity'. Yet, as Pulitzer Prize-winning historian Laura Thatcher Ulrich (1990:202) observes, 'there is a creative tension between pens and needles, hands and tongues, written and non-written forms of female expression, inviting us not only to take oral traditions and material sources more seriously ... but also to examine the roots of the written documents we take so much for granted'. Ulrich advocates that scholars not only examine the textiles themselves but also to use the textiles as a springboard for investigations into all that is associated in the making and using of them. 
In this article, I argue that quilts intimately intersect with the study of materiality and narratives. Certainly, as an object, a quilt has materiality. It can, through standard material culture object analysis, be described in terms of design elements (in other words, colour, texture, pattern, embellishment, and so on) and its physical structure (types of fabrics and construction techniques used, size, condition, and so on). Although they sometimes do, the majority of quilts do not contain words, phrases, and/or passages of text. The connection of these textiles to narratives - in other words, personal and collective life experiences, beliefs, observations, or creative ideas - might at least partially be revealed by clues derived through object analysis. And, within the stories of the making and use of the quilt, the relevance and importance of the object to human experience can be even more fully revealed.

Scholars of quilts have observed the paucity of written documents left by women as compared to men and have pointed out the importance of quilts as historical texts. For instance, in their 1978 Hearts and Hands: Women, Quilts, and American Society, Pat Ferrero, Elaine Hedges, and Julie Silber (1987:11) observe that quilt artists themselves, particularly in the United States, realised how their textiles served as documentation of their lives,

[w] hen nineteenth-century women described their quilts as "bound volumes of hieroglyphics" or as their "albums" and their "di'ries" they were fully aware of what we have recently newly recognised: that their stitched fabrics were often the most eloquent records of their lives ... For vast numbers of nineteenthcentury women, their needles became their pens and quilts their eminently expressive texts.

Early feminist South African author, Olive Schreiner, whose fiction contained references to embroidery and patchwork, likewise recognises textiles as both art and text. 'The poet, when his heart is weighted, writes a sonnet, and the painter paints a picture, and the thinker throws himself into the world of action; but the woman is only a woman, what has she but her needle? ... Has the pen or pencil dipped so deep in the blood of the human race as the needle?' (Schreiner 1982:187).

Though Schreiner, Ferrero, Hedges and Silber speak of these textiles as accounts of women's experiences in the past, the importance of being able to "see" and "understand" the texts afforded by textiles is equally true with contemporary textiles. And, unlike the painstaking and sometimes impossible work of trying to reconstruct histories through the fragments of extant textiles made by anonymous makers, today's researchers often have the advantage of not only seeing the entire textile but, more importantly, being able to have direct access to the maker's stories of the making and meaning of their work. As scholar and textile artist Rachel May (2018) observes, "in understanding how to "read" historic sewn by women ... [one] can use this knowledge to understand sewn-and-written 
work by women today’. Feminist art historian, Rozsika Parker (1984:14-15), in referencing Schreiner's quest to have textiles, particularly embroidery, valued as art, stated that Schreiner 'also perceived the bond that embroidery forged between women; sewing allowed women to sit together without feeling they were neglecting their families, wasting time, or betraying their husbands by maintaining independent social bonds'. Through interrogation of textiles as texts, the social bonds between women, between makers and their communities, can be revealed and the contexts in which narratives are presented materially can be better understood.

\section{Quiltmaking in the United States and South Africa: a brief overview}

Quiltmaking is an art form that can be found in communities and cultures around the world, but it has been a particularly strong material culture tradition in northern Europe and in those countries - such as the United States and South Africa - which share intertwined political, social, and economic histories with the British Empire. Sometimes the terminology used in South Africa and the United States to describe a quilt or a component of a quilt might differ, but the basics of a quilt - a whole textile, usually rectangular in format, made by piecing and/or patching separate scraps of fabric together and intended either for use as a bed cover or a wall hanging - are recognised in common across passage of time and extent of space (Nettleton 2019).

In both countries, indigenous peoples sewed together animal hides for bedding and clothing (du Plessis 2017; MacDowell \& Dewhurst 1997), but the tradition of using patchwork, appliqué, and piecework to make textiles for bedding and as art, was primarily introduced to North America through settlers from Great Britain. The tradition spread fairly quickly and the numbers of individuals who have been historically engaged and continue to be involved in this form of artmaking in the United States, as evidenced in both historical and contemporary accounts, is staggering. The number of quilts made in total is not known, but collected data confirms that it is likely in the millions. According to the most recent edition of a periodic survey of the quilt industry in America, 'there are an estimated 7-10 million quilters in the U.S. and the total number of households with a quilter is 6-8.3 million' (The Quilting in America 2017 Survey 2017).

Although it is likely that the Dutch and French brought quilts with them as they settled in South Africa as early as the 1600s, the earliest known examples of quilts in the colonial era appear to be affiliated with the British and Irish, who immigrated to South Africa when the diamond and mining industries were established. Recently, a quilt dated as early as circa 1805 has been identified (Havenga 2020). As Indian immigrants to South Africa introduced their textile traditions into the cultural mix, their patched and appliquéd bedcovers were, and are still, used in some homes (Areington 2015). Even though in the twentieth century interest in quiltmaking was exploding in the United States and other 
parts of the world, the development of quilting in South Africa was slower owing to several factors, including that it was an art form affiliated with a minority population. As quilt history publications, how-to books and periodicals, exhibitions, and even television and radio shows devoted to quilts proliferated elsewhere, particularly in the United States, these resources were seldom produced in or found their way to South Africa until the new democratic government was established in 1994. The end of apartheid, the opening up of communication channels and travel, and the establishment of the internet enabled South Africans to access new materials and information about quiltmaking worldwide.

While the engagement of individuals in the art of making quilts has a long and expanding history, it should be noted that this engagement, particularly in South Africa, has been conditioned by economic and racial factors. First, since the art form is associated with a colonial rather than an indigenous heritage, quiltmaking in South Africa gained enormous popularity within predominately populations of South Africans of European, and specifically British, descent. Secondly, the costs associated with quilting also limited engagement. For even though quilts can be made with recycled fabric and tools consisting only of thread and a needle, the new era of quiltmaking promoted production of work made of new fabrics, even cloth made especially for quilts. Sewing machine manufacturers continually produce machines that incorporate increasingly sophisticated computer programming and are accordingly more expensive. The purchase of new cloth and such technologically advanced machines rendered the making of quilts financially out of reach for many.

Two groups of fibre artists in South Africa have been driving forces in the expansion of interest in the making and appreciation of quiltmaking. The South African Quilters' Guild, whose membership of over 5000 largely comprises white South Africans, was founded in 1989, and has twelve affiliated regional guilds. Members stage major regional and national exhibitions, offer instructional workshops - especially in informal communities - maintain website resources, and conduct studies and documentation of historical quilts. Fibreworks (see fibreworksart.com), formed in 1997, likewise had a tremendous influence on quiltmaking activities, particularly in the acceptance of quilts within the realms of the fine arts market, curatorial, and scholarship world. Fibreworks exhibitions, mounted at Nova Constantia and at other venues in South Africa and worldwide, have brought critical acclaim to textile works and have encouraged fibre artists to continually engage in experimental work.

Under the new democratic government there was also an outburst in the formation of economic development initiatives, especially for rural and disadvantaged communities, which have been a factor in the slowly growing engagement of non-white South Africans 
in making quilts and related textiles. Led by non-governmental organisations (NGOs), religious and service organisations, artist-activists, and governmental agencies, these initiatives aimed to tap women's traditional skills, especially in sewing and beadwork, to develop marketable products for income generation for the artists. Most quilts made around the world were intended for use as bedding and thus the majority of this output has simply been "used up". Many though have been preserved, especially when they represented a family heirloom passed down from one generation to the next; these textiles - often accompanied by a family story - are tangible evidence of the lived experiences and the creativity of forbears. Quilts intentionally made as art, such as those done by countless textile artists in the United States and South Africa, are treasured for both the visual statements they make and the stories they convey.

\section{Quilt documentation and study}

Quilt studies began to come of age in the mid- to late-twentieth century, and by the end of the century, a body of scholarship on quilts, quiltmaking, and quilt artists, especially of the history of the activity in America, had been well established. Much of this scholarship was based on data from the documentation projects and constituted analysis seen through primarily historical, material culture, and art historical lens. Published work emphasised physical descriptions of quilts, biographical sketches of individual artists or communities, and descriptions about time or place-based traditions and businesses. Yet, the vast amount of data on their materiality and their associated narratives was ripe for analysis through multiple disciplinary lenses and through critical theories, such as thing theory, care theory, feminist theory, and literary theory. Quilts and their stories were embraced as part of thematic or area studies of health, feminism, gender, race, ethnicity, occupation, religion, and sociology.

Systematic documentation of quilts held in private and public collections began in the late-twentieth century in the United States, when grassroots citizen scholars joined with academic scholars and staff at museums, libraries, and archives to organise quilt documentation projects across regions (in other words, counties, states, provinces, and nations). Images, stories, and technical data on tens of thousands of quilts, along with biographical data about their makers and their social histories have been gathered. It has been estimated that the local, state, and regional quilt documentation projects begun in the 1980s have already registered data on over several hundred thousands of historical quilts in the United States (see Christopherson 1995; Zegart \& Holstein 1993; Zegart 1996). In the early 1990s, members of the South African Quilters' Guild began documenting quilts made prior to 1960 that were held in museums and private collections; Voortrekker quilts (lappies komberse) and kappies (bonnets with extensive quilting on the rims) were of special interest to the guild researchers (Kirk [sa]). The Quilt Index (www. 
quiltindex.org), a freely-accessible online digital humanities resource, serves as the home for over 80000 records from some of those projects, as well as data from other research projects and private and public collections, including hundreds of museums. As of 2020, the Index holds records of approximately half of the state and regional documentation projects conducted in the United States, two provincial projects in Canada, and the records of the South African Quilters' Guild Heritage Project (Quilt Index 2003, South Africa Quilt History Project [sa]).

The study of quilts and related textiles in South Africa is nascent. Exceptional studies have been done on related textiles, such as Brenda Schmahmann's work on the Mapula Embroidery Project and Juliette Leeb-du Toit's examination of the production and use of shweshwe - a fabric favoured by quilt artists in South Africa as well as those identified with the African diaspora (see Schmahmann 2006 and Leeb-du Toit 2017). These fill important gaps in our knowledge about South African's material cultural heritage, but the paucity of scholarly work on quiltmaking in South Africa warrants attention. ${ }^{2}$ We need to know if quilts are in the inventories of early settler household goods, the use of quilt techniques and forms in craft development projects, the role of missionaries introducing quilting techniques to residents of rural communities, the impact that predominately white South African quilting guilds are playing in teaching quilting arts to predominately black South Africans in townships, the biographies of black quilt artists who are finding critical acclaim and financial reward for their work, and the intentionality of quilt makers - why individuals are making this form of textile, especially when commercially manufactured bedcovers can now be so easily and cheaply purchased.

Through studies already done on quilts in other countries, and by using search and compare tools in the Quilt Index, we know that historical quilts made by the United States and in Great Britain and its Commonwealth used similar patterns and materials, thus providing visual documentation of trade routes, patterns of migration and settlement, and the distribution of materials, aesthetic styles, and cultural practices. And, through the stories associated with the making and the histories of those quilts, these textiles are invaluable material documents serving as primary sources to investigate and understand personal and public history.

Intersections of text and textile: A sampling of quilts from the United States and South Africa

One early documented quilt in South Africa was made in circa 1835 by Sarah Pike, the daughter of William Pike, one of the 1820 Settlers who came from Great Britain to the Eastern Cape. The quilt descended through family lines to current owner, Margie Smith (Smith 2011). Given that most of the 1820 Settlers were not well-off, it is remarkable that 
Sarah Pike was able to garner the fabrics and have the time to make this piece that mirrors, in fabric choice and design, quilts being made in Great Britain at that time. Again, Olive Schreiner, in describing the lives of settlers and farmers of colonial South Africa, often refers to the importance of textiles connected to immigrants and their families. 'All her life she had dreamed of having a dress made of thick black silk, with large blue daisies with white centres embroidered in raised silk work all over it at intervals. Her mother had had such a bit of silk in a patchwork quilt she had brought from England with her' (Schreiner 1982:XI). Schreiner's expressive texts belied her acute observations of the prevalence of textile making, including quilts, in this era of South African history. At present, we know little else about the Sarah Pike quilt but, for its owner Margie Smith, the quilt represents tangible evidence of her family's experiences and serves as a visual aid to tell of her family's history (Figure 1a \& Figure 1b).

Little is also known about the origins of an appliquéd and embroidered bedcover acquired by the Michigan State University Museum, East Lansing, Michigan, USA in 2016 (Figure 2). The Etsy online seller provided this information, "[h]ere is a great item from a recent estate. This beautiful hand-made piece is a memorial of The Second Boer War (Oct. 1899 - May 1902), between Great Britain and South Africa. Good condition for its age. "Worked on in 1900 by M. Bimsom". This appears to be unstitched. 2/17/2016' (Michigan State University Museum 2016). From a strictly material culture object analysis basis, we know that, in addition to the inscribed reference to the maker, the textile also carries the embroidered slogan 'United We Stand for Queen and Empire' as well as embroidered names of individuals or groups whose portraits adorn the quilt. Military historian Michael

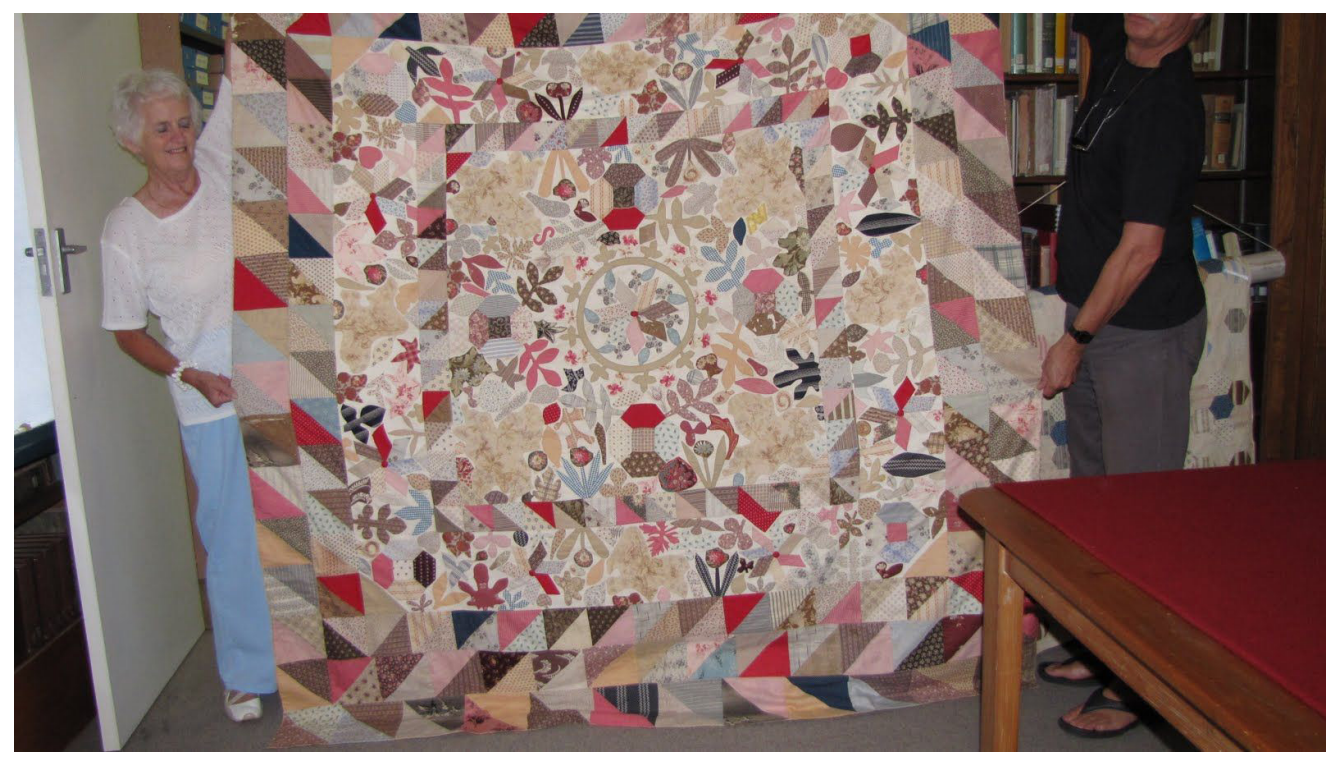

Figure $\mathbf{N}^{0} \mathbf{l a}$

Margie Smith with the quilt made by her forebear Sarah Pike, c. 1835. Photograph by Marsha MacDowell, 2011. 


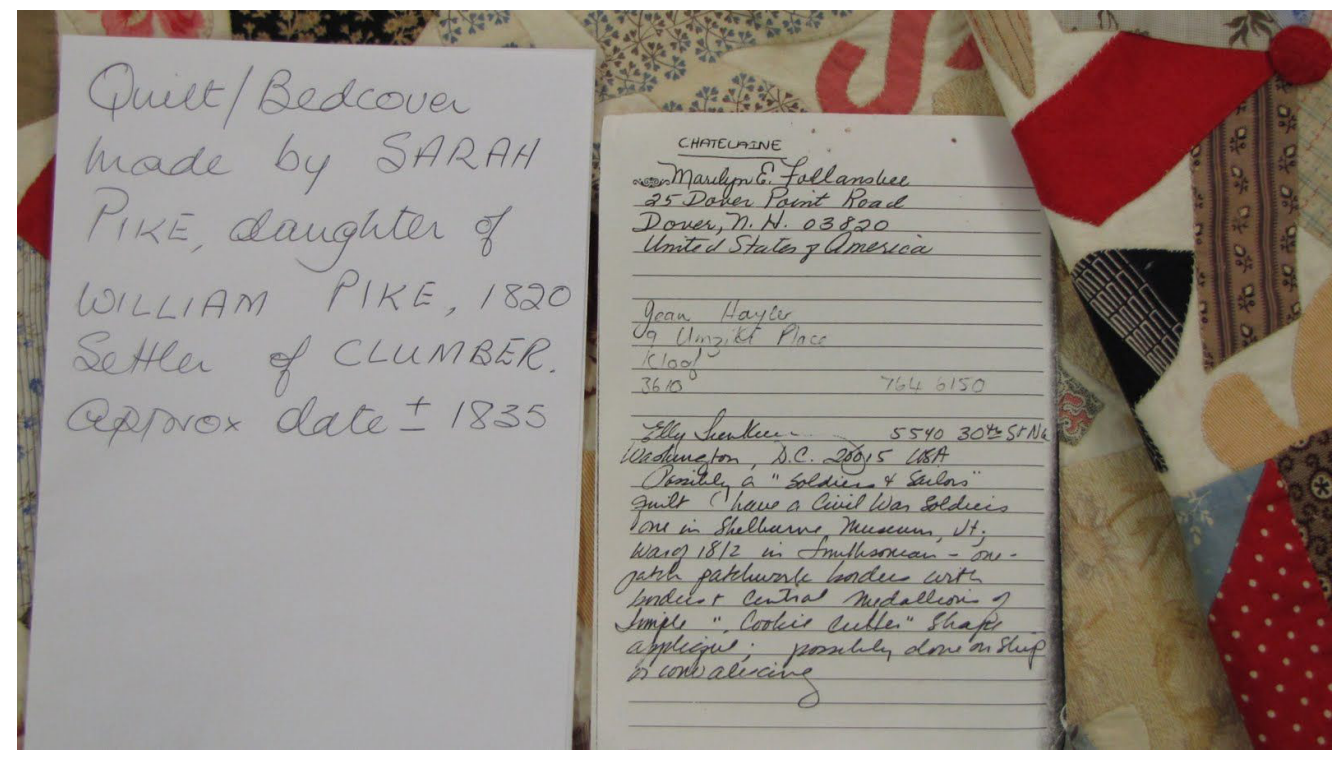

Figure $\mathbf{N}^{\mathbf{0}} \mathbf{l b}$

Notes on the Sarah Pike quilt maintained by Pike's descendant, Margie Smith. Photograph by Marsha MacDowell, 2011.

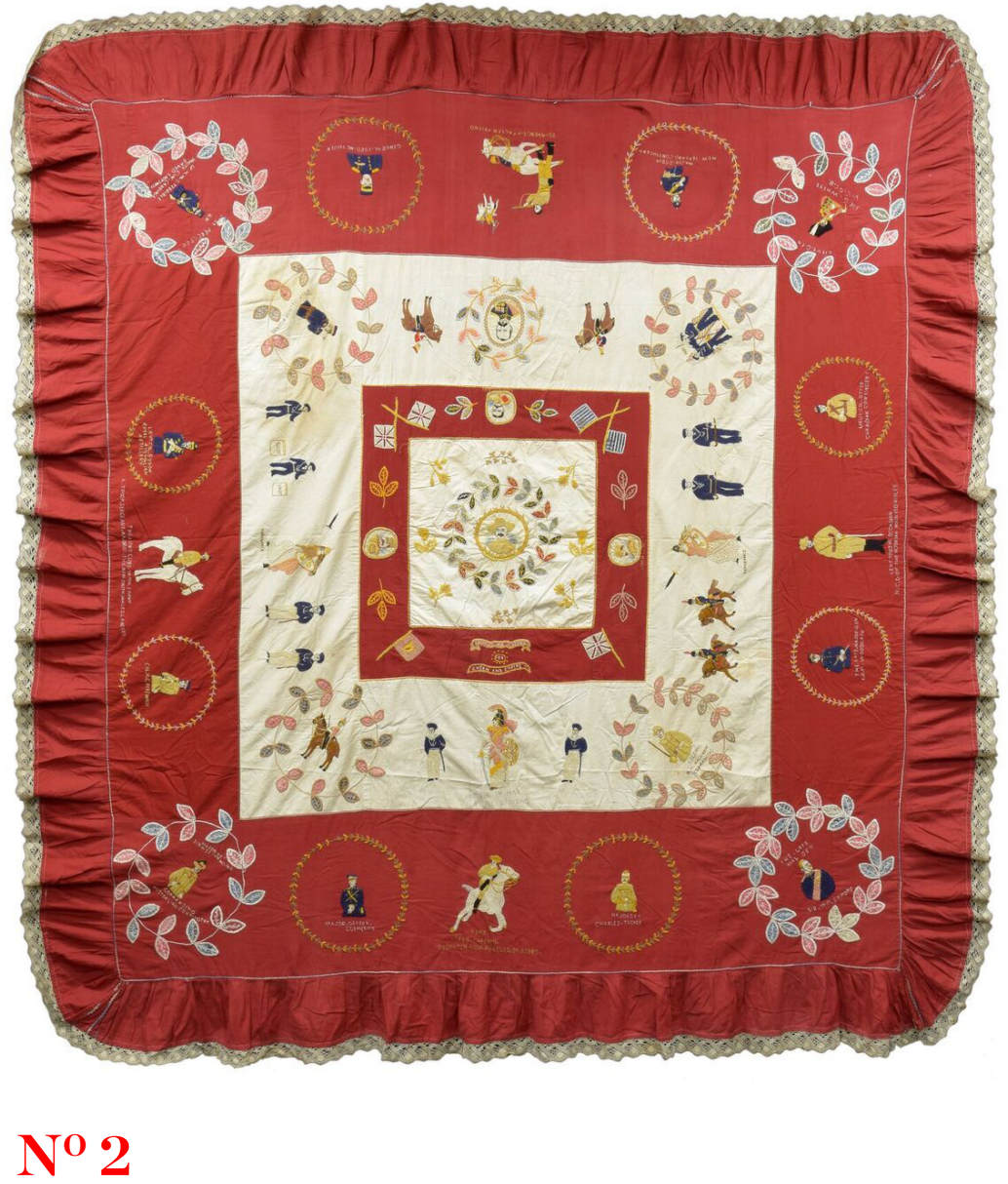

FIGURE No 2

Boer War Quilt made by M. Bimson,1900, provenance unknown. Michigan State University Collection. Photograph by Pearl Yee Wong. 


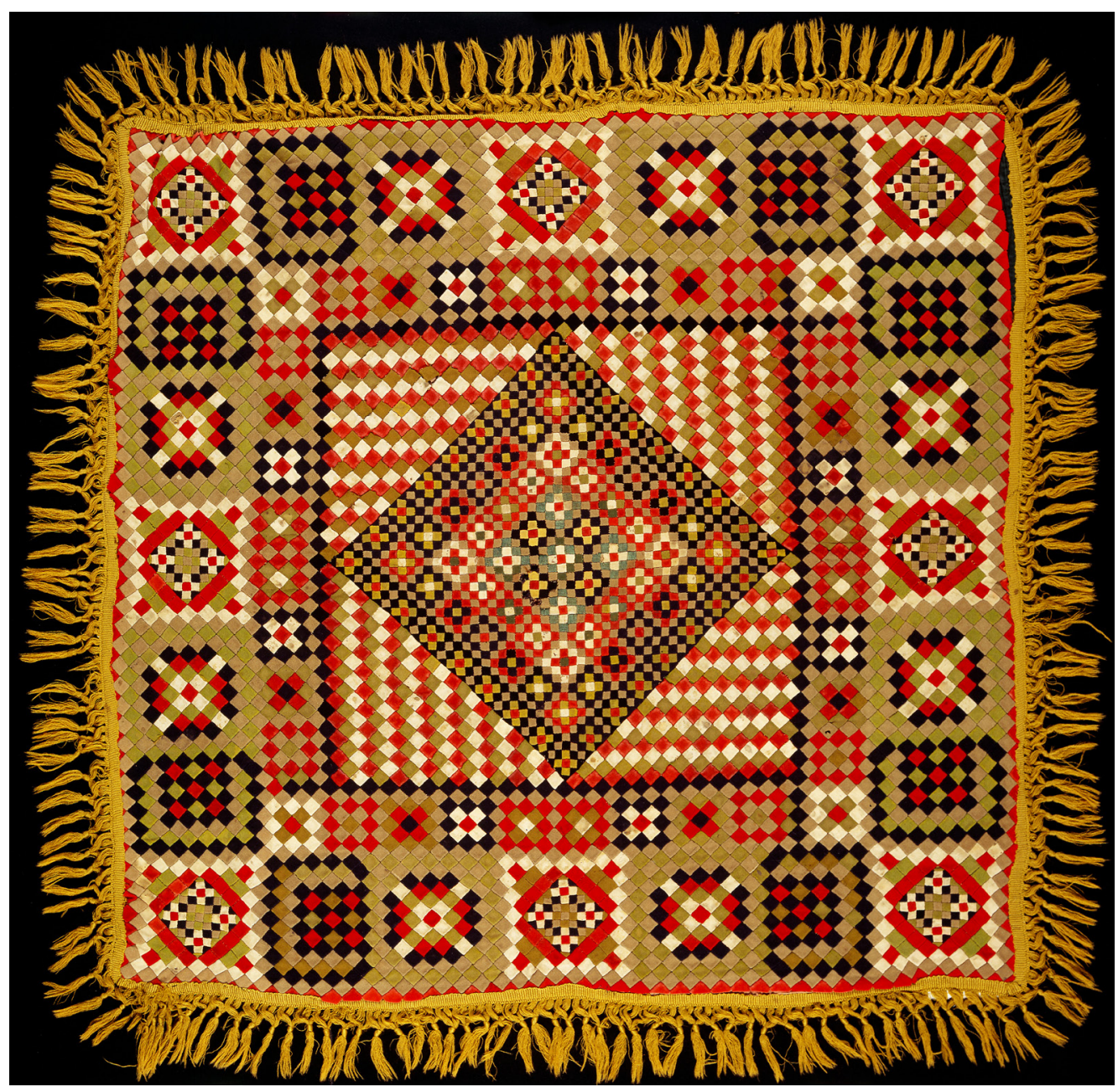

FIGURE No 3

Boer War Quilt made by Millist Vincent II, 1900-05, Tasmania, Australia. Collection of the Tasmanian Museum and Art Gallery, Hobart.

Walwyn, who has done research on the individuals named in the quilt, offers that, "[f]rom the choice of individuals depicted in the quilt, it is fairly clear that the artist was a sympathizer of the British cause. Perhaps it would be more accurate to say "the Empire cause", since many of the characters were from Australia, Canada and New Zealand, which emphasises the extent to which troops were recruited from the Dominions. By way of contrast, there is one unnamed Boer depicted in the quilt!' (Walwyn 2016). Was this quilt an oddity in the corpus of South African quilts? Likely not, as at least three other wartime-themed patched works are now known to exist - all of which incorporate pieces of military uniforms in their construction. The first is also connected to the Boer War and was made in Tasmania, Australia, by war veteran Millist Vincent II (Figure 3). According to the story that - along with the textile itself and a photo of Vincent - was handed down 
three generations in the family, the quilt was made of cut-up pieces of cut-up uniforms from injured soldiers. The quilt and photograph are now in the Tasmanian Museum (Gero 2015:173).

Another quilt, made more recently in South Africa, also documents events and experiences of the Anglo-Boer War. The massive textile piece, designed and made by Naomi Moolman (and quilted by Petro von Rooyen and Magda Kriek) in 2010, was commissioned by the National Women's War Museum located near the War Memorial in Bloemfontein (Figure 4). Moolman gathered historic photographs from the War Museum and from her own collection, and had them printed on cotton. Then she cut the images, now rendered on fabric, and arranged them in three rows of five "windows", each of which contained a tableau. The top row is of family photographs during the last 30 years of the nineteenth century, the second row focuses on the Anglo-Boer War when Boer settlements were burnt and women and children were sent to prisoner of war camps, and the third row examines the return of Boers to homes in the post-war period of the 1920s. During periodic special programs at the Museum, Moolman stands near her quilt and tells visitors about the stories connected to the objects and images. As one viewer of the quilt stated, '[t]his quilt is an extraordinary testimony to the challenges of everyday life and war in a turbulent period of history. My historical knowledge is poor, and this was a wake-up call, reminding me how fortunate many of us are to live our comfortable lives without the sorts of struggles that these women endured' (Ball 2014; Heunis 2010). At once the quilt is a meta-object filled with hundreds of textile objects and stories, and Moolman uses it to narrate her personally-curated understanding of history.

Another quilt related to conflict in South Africa is by an unknown maker and in a private collection in Australia. Australian quilt scholar Annette Gero, who curated an exhibition and wrote an accompanying book on wartime quilts, describes the material features of this piece,

[t]his extraordinary woolen military quilt, with thousands of tiny patches, was made in the 19th century from military uniforms and is all hand sewn. The double edging is "pinked"3 and the inner squares of tiny diamonds have embroideries of British crowns and flags. Several other embroideries show native huts, spears and shields, a drum and anchors. Because all of the embroidery refers to the Zulu War, one can assume it was made on site or later when the soldiers returned home. The Zulu warriors' equipment was the shield and the stabbing spear which appear on the quilt (Gero 2015:38).

A fourth example of patchwork related to conflicts in South Africa is an unfinished table cover in the collections of the Durban Local History Museum. While not a quilt per se, in its construction the maker used the common mosaic patchwork pattern and English paper piecing technique, both of which were popular in Britain and in South Africa at the 


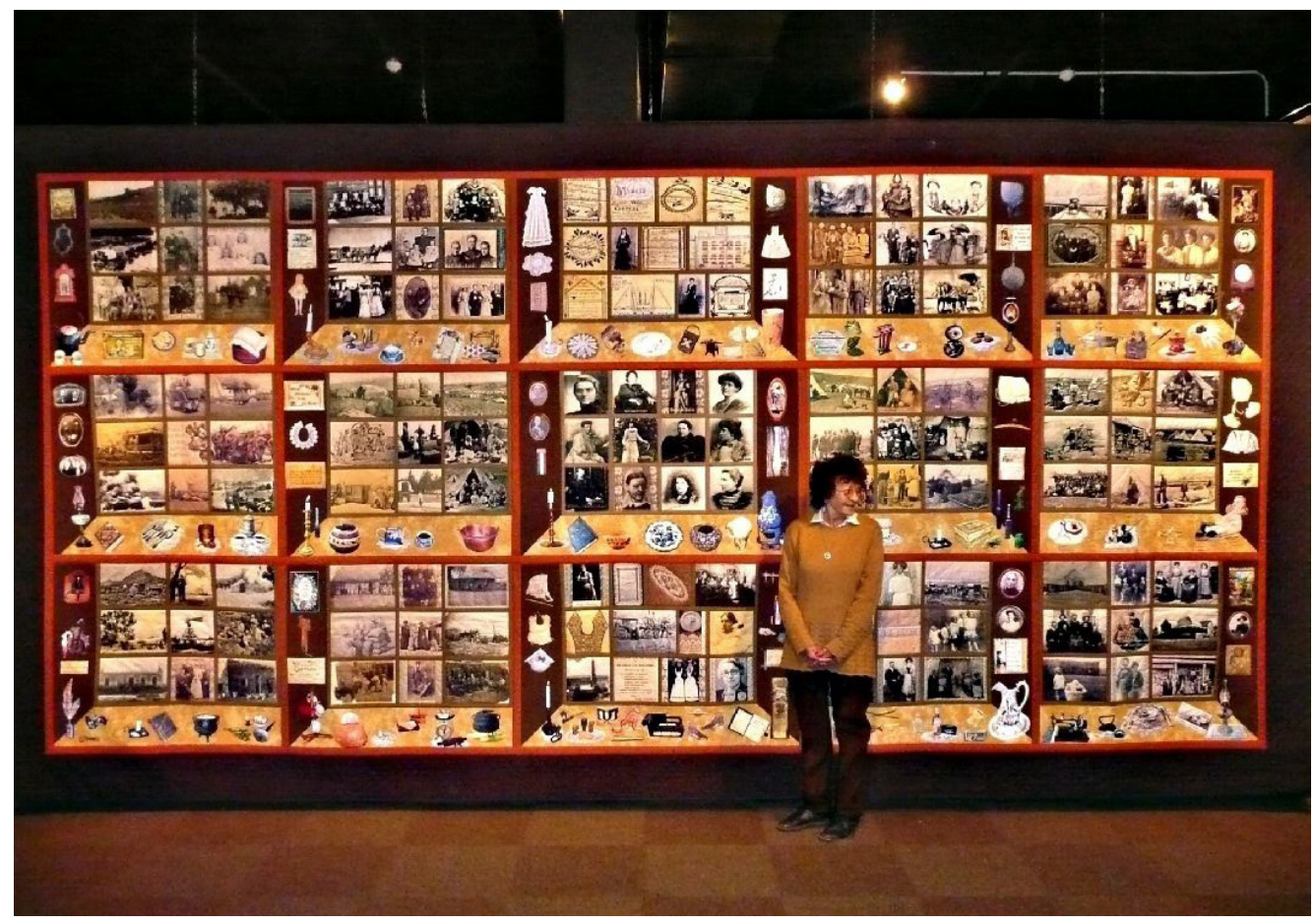

FIGURE $\mathbf{N}^{\mathbf{O}} \mathbf{4}$

Heritage Quilt of the Boer Republics designed and constructed by Naomi Moolman, quilted by Petro von Rooyen and Magda Kriek, 2010. Collection of The War Museum of the Boer Republics, Bloemfontein.

time. ${ }^{4}$ According to a note accompanying the textile, it was sent to South Africa from Surrey in the UK, and was made by a soldier of cloth from uniforms of men who served in the Zulu War (Hexagon Stars 2020). In all four cases, these textiles shed glimpses of both the corporate and individual experiences of wars in South Africa. Yet, at the same time, these textiles prompt many questions, including about complete provenance, authorship, maker's motivation, the tradition of using military uniform fabric in textiles, and the history of the quilt as it passed from the original owner to current owners.

Indigenous, settlers and immigrants in the United States and in South Africa have continuously used patched and appliquéd textiles to make quilts for domestic uses. At the same time, a growing number of individuals began to employ quilts as a medium to convey stories of personal experiences, to advocate for social justice, and to memorialise history. South African artist, Sandra Kriel, powerfully coupled her activism and her needlework skills to convey stories that she felt were important about the political struggles of the apartheid era (Miller 2013). In many works, including those in her For the Fallen series, Kriel employed patchwork, photo-transfers on fabric, and embroidered text in art to intentionally memorialise struggle heroes and to raise consciousness about 
apartheid and human rights. During the anti-apartheid movement, Kriel (2017) states that she was spending her free time in meetings, marches, and defiantly organising resistance,

\begin{abstract}
[a]lthough I studied painting, I had no time in those years for the isolation of studio painting. But I needed to be creative so I put together a little suitcase with materials for embroidery and carried it with me to the meetings. Whatever was discussed in these meetings, was stitched into the cloth. Needle and thread became the medium through which history was interpreted and communicated. Every stitch was dedicated to those who lost their lives in their struggle for justice.
\end{abstract}

In the centre of this piece (Figure 5), done as part of the For the Fallen Series, Kriel incorporates a photograph of Matthew Goniwe, Fort Calata, Sparrow Mkhonto and Sicelo Mhlauli, black South African anti-apartheid activists known as the Cradock Four. Above and below the image are the embroidered words 'Order to Kill, June 7 1985' and 'Killed June 17, 1985', and the names of those killed. Though quilts are often perceived of as comforting, this piece belies that perception. The juxtaposition of domestic textile techniques with layered images and text of brutality and death is disquieting. Her quilts convey political critique and offer a form of remembrance and resistance. Kriel's are powerful examples of the intersection of textiles and texts, where the materiality of the object and its literal and associated texts provide rich ground for close-looking and multilayered analysis.

In 2015, the Michigan State University Museum acquired a quilt made by American math professor and activist quilt artist, Chawne Kimber (Figure 6). Her quilt, entitled The One for Eric G, carries the repeated phrase 'I Can't Breathe'. Even when this quilt explicitly contains text, we would not be able to comprehend its meaning unless we are also aware of American history and the prevalence of police brutality and, specifically, that this phrase was connected to the last utterances of Eric Garner, an African American who was killed by police the year before the quilt was made. Although countless other instances of police brutality were little recognised, if at all, by the media before the murder of Garner, his death 'was the start of a succession of police killings that captured national attention and ignited debate over race and law enforcement' in the United States (Baker, Goodman \& Mueller 2015).

When we realise the connection of the quilt's repeated phrase 'I Can't Breathe' to the murder of Garner, we can "read" that the lettered words transition from clear white the first time it appears near the top of the quilt, to its last iteration at the bottom of the quilt when the words are the blue of death. However, Kimber's own story about this quilt amplifies her intent as an artist and as an African American to convey its cultural relevance and her personal anger through the design of the piece. As Kimber states, 


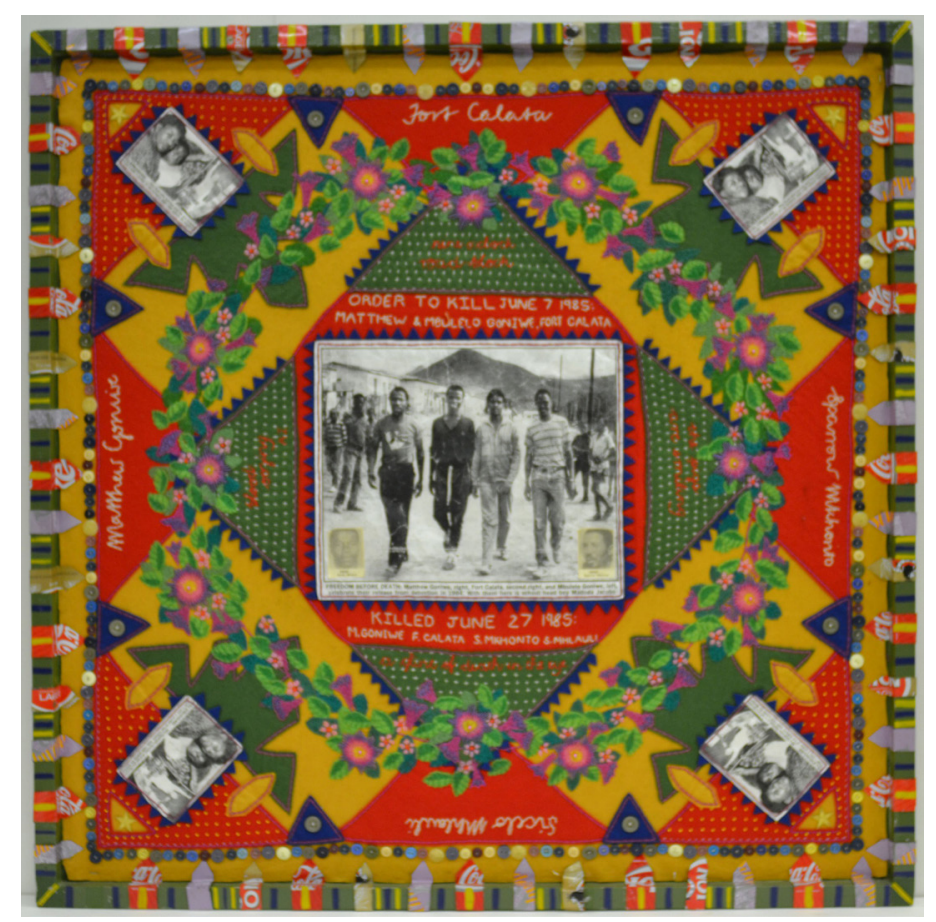

FIGURE $\mathbf{N}^{\mathbf{0}} \mathbf{5}$

Cradock Four from For the Fallen series made by Sandra Kriel 1991-92. Collection of the Mayibuye Centre, University of Western Cape.

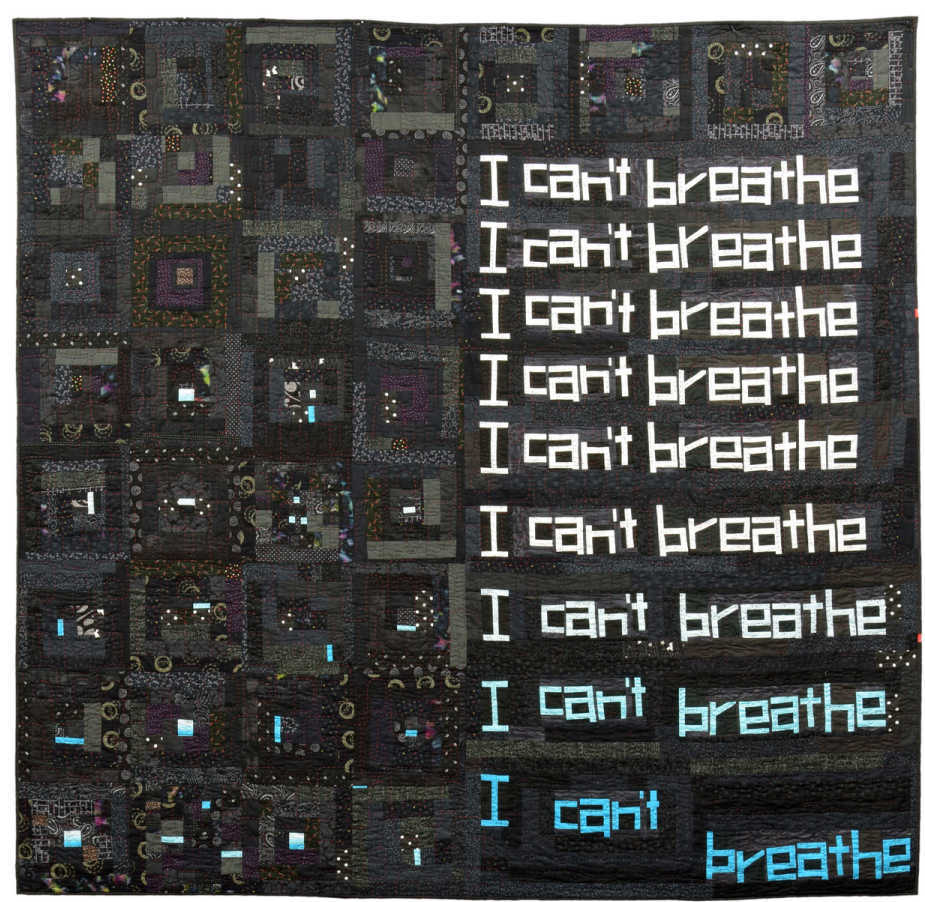

Figure $\mathbf{N}^{\mathbf{0}} \mathbf{6}$

The One for Eric G quilt made in 2015 by Chawne Kimber, Michigan State University Collection. Photograph by Pearl Yee Wong. 
The improvisational patchwork here is meant to remind one of graffiti scrawled impulsively on a wall in the shadows. Hand-quilting in winding trails of various reds invokes brick and blood ... this one is for Eric Garner who was killed in a chokehold by NYPD [New York Police Department] officer Daniel Pantaleo on July 17, 2014 on Staten Island. His suspected crime was selling loose cigarettes on a street corner. Recorded in a viral video on a smart phone, these were Eric's last words. For me, these words are filled with meaning beyond the incident (Kimber cited by Hlohowskyj 2017).

Kimber has placed her quilt within an African American aesthetic context. Her description of the intentional use of red threads to invoke blood and bricks helps us to link this object more closely with police and urban violence against African Americans. Her reference to graffiti calls out a subversive practice that is most often carried out by those who do not have access to officially sanctioned forms of public expression or who are excluded from the art world. Quilts, like graffiti, have been, until relatively recently, expressive art forms that have been largely marginalised by art scholars. Kimber's quilt could be seen as placing the proverbial writing on the wall; Kimber merges the expressive art forms of graffiti and textiles. Kimber speaks of the improvisational nature of the patchwork and that this improvisation is meant to convey the sense of something that emerges from a place of impulse, a place of feeling rather than something carefully pre-meditated, and also as something that occurs in the shadows. Both quilts and graffiti are produced in the shadows. Quilts are typically made in the private spaces of home or studio; graffiti is done publicly but clandestinely, often in the cover of night darkness. ${ }^{5}$

In other recorded narratives, Kimber also ties her work to the histories of her own families, '[t]hrough the cultivation of cotton in rural Alabama, some of my ancestors (unwillingly) participated in the building of the United States. Cotton has been central in the lives of the women of my family - from picking to ginning to sewing, with quilting emerging as the main mode of self-expression available' (Kimber 2020). Cotton, slavery, wealth distribution, and violence are intimately linked in United States history, and the enormous wealth accrued by those in America involved in the cotton industry directly led to the incredulous disparities in wealth between Blacks and Whites in America as well as the culture of violence against Blacks that continues into the twenty-first century (Lockhart 2019). In Kimber's own words, expressed orally and materially, she invokes the historical roots and the contemporary continuation of racism.

\section{Collective projects engaging women in making narrative textiles}

Several projects instigated by artist-activists or non-government organisations in South Africa encouraged the use of piecework, patchwork, and embroidery to create narrative textiles that depicted stories of their makers' personal and community experiences. When 
textile artists have so been encouraged, the resulting textiles are material documents of difficulty histories, of racism, xenophobia, police brutality, of economic hardship, and domestic abuse.

One such project, Amazwi Abesifazane (Voices of Women), under the auspices of NGO Create Africa South, has enabled over 2000 rural, mainly disadvantaged and often illiterate women, to share their stories in recorded oral and textile narratives. ${ }^{6}$ Their memory cloths typically render their responses to story prompts such as 'tell me a day you will never forget' or 'tell me what democracy means to you' (see Webber 2013; Becker 2007; Botha 2007; MacDowell \& Dewhurst 2005). These material depictions by the artists of especially horrific, inspiring, or poignant experiences etched into their memories provide histories of marginalised women not otherwise recorded about South Africa during and immediately after apartheid. As art historian Carol Becker (2007:118) states, '[e]ach cloth is a bit of archival information. Each act of telling - in this case, actually making the cloths - brings another story filled with important historical and cultural data into the public arena'. Through the facilitation of such collective bodies of memory cloths, sometimes described by scholars as community archives, these projects have resulted in profoundly important collections of gendered historical memories (McEwan 2003).

In Isiphethu, a craft-based economic development sewing project headquartered at the Carnegie Art Gallery in Newcastle, South Africa, black South African artists deftly incorporate patchwork and embroidery into their memory cloths (Figure 7). Cynthia Msibi (2010) had the following to say about her graphically compelling textile,

[h]ere people are seen being rescued by the police after the angry community members attacked them, here the shops have been closed because they've been broken into. And women and their children have [sic] ran to the police for some help as the other community members approach. The police tried so hard to calm the situation as the members of the community are angry saying that the foreigners are taking their jobs from them causing them to be poor so they must be sent back to wherever they are coming from.

Msibi's story amplifies what her visually striking piece attests to her own black South African's fear of police and police dogs, and her concerns about societal conflicts, racial inequality, and xenophobic attitudes.

Textile documents of everyday life experiences, personal ideas, and individual beliefs

Of course, many story textiles simply convey images of experiences, places, and ideas important to the maker. Betty Mgidi, a deeply religious Ndebele woman, worked as a domestic for a Johannesburg-based artist who taught her the rudiments of quilting. In 


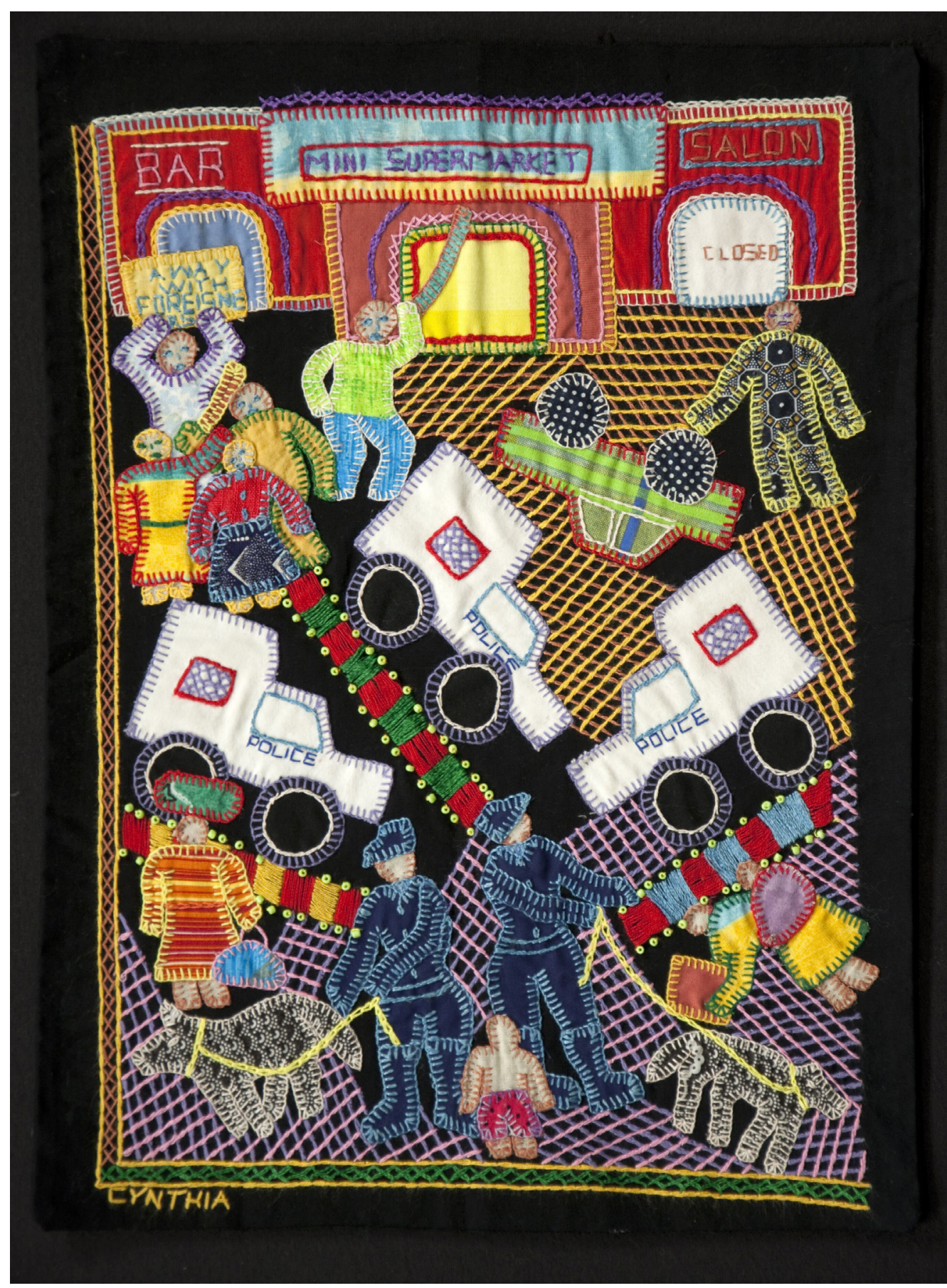

FIGURE $\mathbf{N}^{\mathbf{0}} 7$

Xenophobia, memory cloth made by Cynthia Msibi, 2010, Newcastle, KwaZulu-Natal Province, South Africa. Michigan State University Museum Collection. Photography by Pearl Yee Wong.

one of her pieces, designed as wall hanging, Mgidi rendered a place important to her - the façade of a Roman Catholic Church in her home community of Mabhoko, South Africa (Figure 8). The clouds, trees, and mountains in her work are done in quilted stitches 


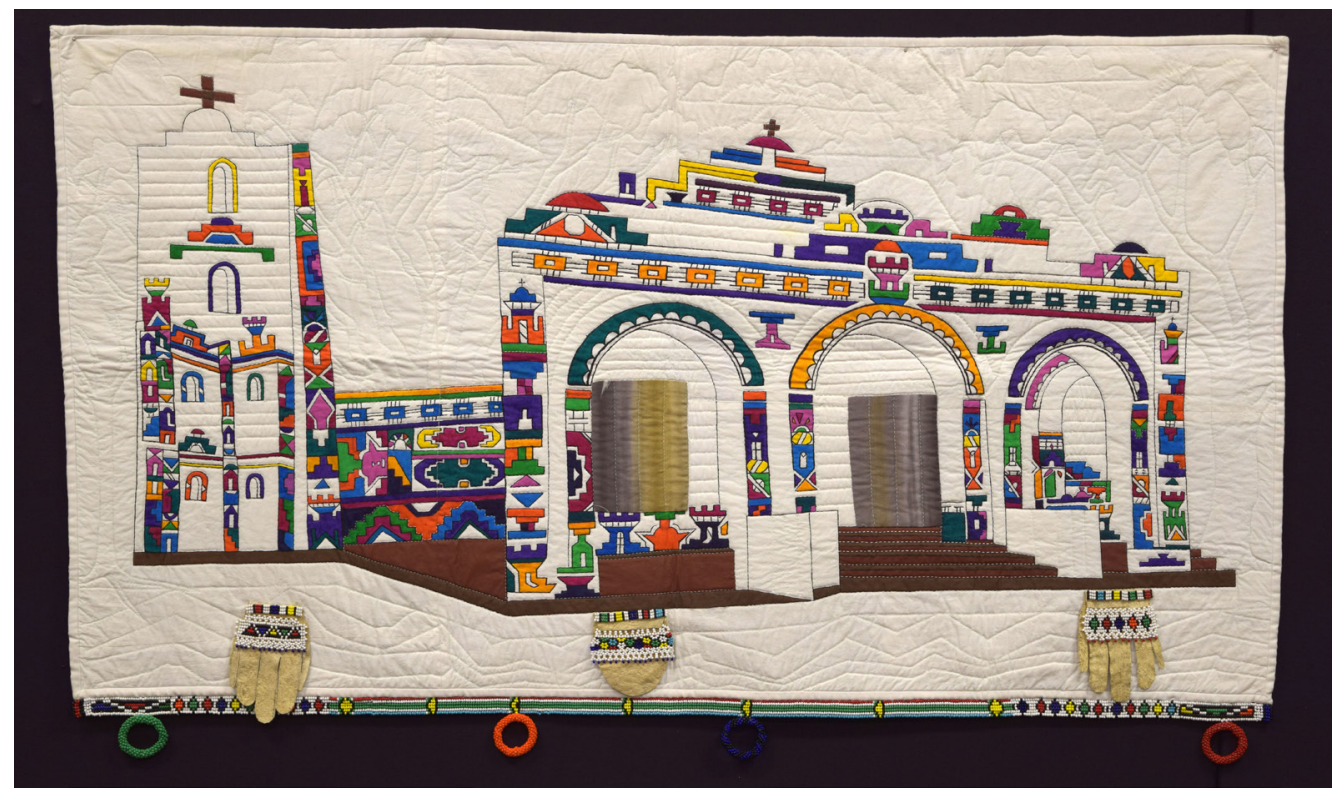

FIGURE No 8

House of Faith (Indluyenkolo) quilt made by Betty Mgidi, 2010, Johannesburg, South Africa. Michigan State University Museum Collection. Photography by Pearl Yee Wong.

but, just as Ndebele women decorate homes and community buildings with painted graphic designs, Mgidi decorates her depicted buildings with fabric paints or markers. In talking about her quiltmaking and her choice of subjects, Mgidi shared that working on her quilted and painted textile pieces was calming and helped her to remember her own home (Mgidi 2011).

\section{Entwining local and global histories through quilts and stories}

In the post-apartheid era, the interactions between American and South African quilt artists have increased through digital connections and face-to-face interaction. Wellknown American art quiltmakers, such as Ricky Timms and Nancy Crow, have conducted workshops for South African quilt guilds, and South African quilt artists such as Jenny Hearn and Odette Tolksdorf have shown their work in major exhibitions and festivals in America (Hearn 2013; Tolksdorf 2011). In 2016, members of Fibreworks and the South African Quilters' Guild joined with artists who were members of the US-based Women of Color Quilters Network to make quilts for an exhibition in tribute to Desmond and Leah Tutu. Many of the artists incorporated text into their work; all provided written stories of what the Tutus meant to them and what their work illustrated. Diane Vandeyar, a member of the Cape Quilters Guild, the Good Hope Quilters Guild, and Fibre Artist Cape Town Group (FACT), used text and fabric to convey her admiration for the Tutus and creatively 
combined the name Tutu with the word ubuntu, a Nguni word that roughly means "human kindness" (Figure 9). Vandeyar shares that,

Benny Gool's photograph [used with his permission] of the Tutus was the perfect focal point for my quilt. I used a photo transfer technique to print the images of the hands and faces onto different individual pieces of fabric ... The rainbow over the Tutus was made with African fabrics. It is a tribute to all the people of the South African Rainbow Nation (MacDowell \& Brown 2016:2).

Vandevar also points out that, '[a] large portion of the quilt uses liturgical colours, such as purple, violet, rose and pink, representing Archbishop Tutu's devotion to the clergy' (MacDowell \& Brown 2016:67).

Quilts made in South Africa now reside in private and public collections around the world; quilts made in the United States now reside in museum collections in South Africa. These textiles and the accompanying stories of who made them, when and why they were made and how they were used, and who now owns them and how their stories are interpreted and carried forward, be it by scholars, family members, curators, or digital indices, are important. They contribute to our understanding of multi-layered, intertwined histories of people and places.

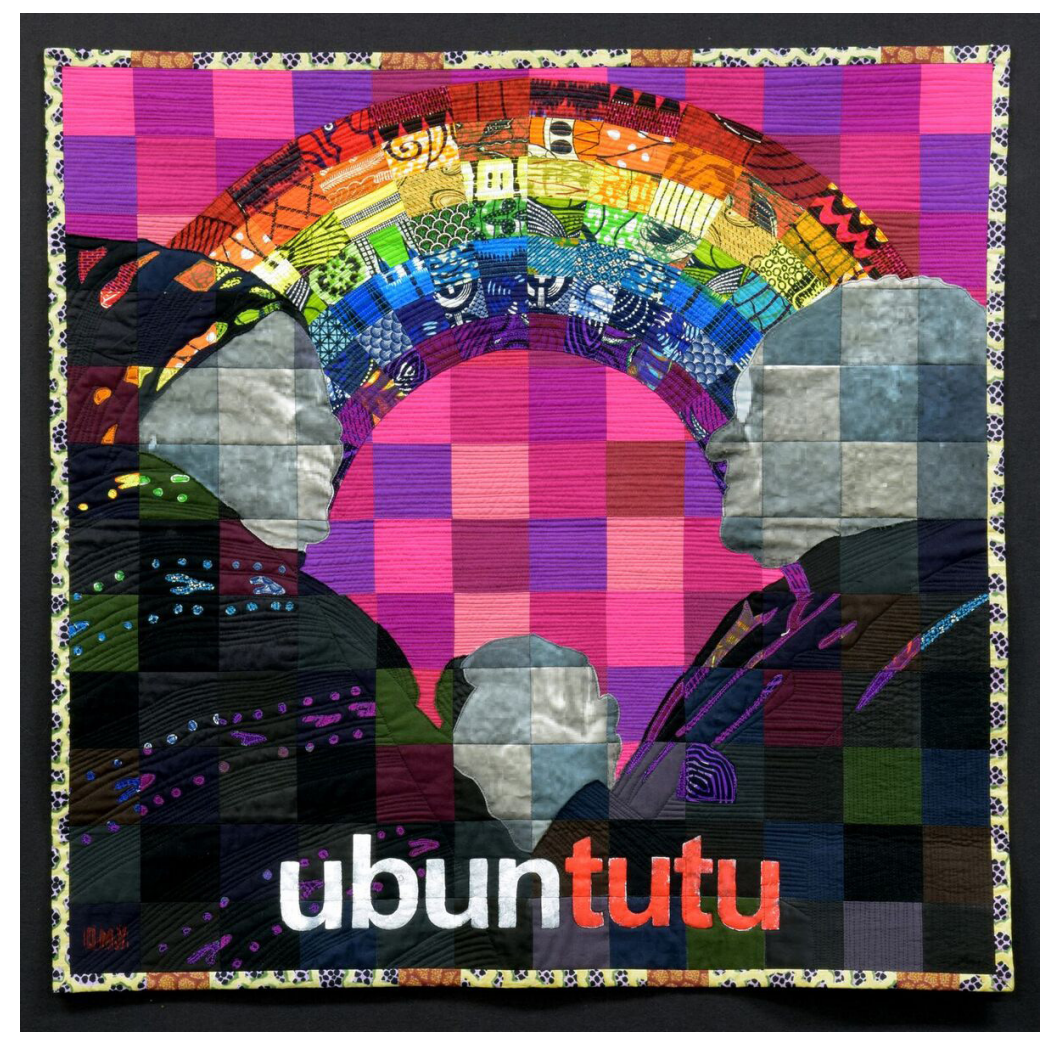

FIGURE NO 9

Ubuntutu, made by Diane Vandeyar, 2016, Cape Town, Western Cape, South Africa, Michigan State University Museum Collection. 


\section{A closing note}

The examples highlighted above clearly support the ways in which quilts and related textiles both materially and with their associated stories - especially those gleaned from the makers themselves - are critical resources for understanding the human experience. When Olive Schreiner (1982:IX) asked, '[h]as the pen or pencil dipped so deep in the blood of the human race as the needle?', she must have been acutely aware of the many, many individuals in her family and in her community who used thread, needle, and fabric to not only serve domestic needs, but also to serve as touchstones and conveyors of the lived life of the textile's makers and users. It is essential that we interrogate and understand how these objects and their stories are part of human interactions, not only within and at the time of the contexts of their original making, but also why and how their material messages continue to have resonance and meaning.

Fiber artist and writer Maria Hlohowskyj, observes that Chawne Kimber 'often writes about the power that we give to or take away from language. We can give or take power from quilts, too, and more often than not we have dismissed them as feminine, domestic items with little to say. Like her South African counterparts in textile storytelling, Kimber is taking back that power, one stitch at a time' (Hlohowskyj 2017). As more quilts are documented and analysed and as more quilt history is investigated, documented and analysed, we will, without a doubt, understand that quilts and related textiles have, indeed, much to say.

\section{Notes}

1. The author wishes to thank the reviewers of this manuscript for their close reading and excellent suggestions which have immensely strengthened this article.

2. For the best historical published references to patchwork and quiltmaking in South Africa, see JC Pretorius (1992).

3. Pinking refers to the process of cutting a textile with pinking scissors, the blades of which are sawtoothed instead of straight. When used to cut materials, it leaves a zigzag rather than a straight edge.

4. The English paper piecing technique consists of stabilising fabric around a paper shape, usually a hexagon, before sewing the pieces together to create an overall design.

5. The author wishes to especially thank the anonymous reviewer for her insightful suggestions regarding graffiti.

6. Images and texts of the memory cloths can be accessed in Reclaiming Heritage: A Living Archive, available online at https://www.amazwi-voicesofwomen.com/archives. 


\section{References}

Amazwi Abesifazane - Voices of Women Museum. [Sa]. Reclaiming heritage: A living archive. [O]. Available:

https://www.amazwi-voicesofwomen.com/archives Accessed 23 July 2020.

Areington, ZK. 2015. Personal communication with author, 26 August. Johannesburg, South Africa.

Baker, A, Goodman, JD \& Mueller, B. 2015. Beyond the chokehold: The path to Eric Garner's death. [O]. Available: https://www.nytimes.com/2015/06/14/nyregion/eric-garner-police-chokeholdstaten-island.html.

Accessed 23 July 2020.

Ball, M. 2014. South African quilt festival \#7, heritage quilt, Dragonfly quilts. [O]. Available: http://www.dragonflyquilts.com/weblog/?p=1010. Accessed 23 July 2020.

Barber, E. 1994. Women's work: The dirst 20,000 years - Women, cloth, and society in early times. New York: W. W. Norton and Company, Inc.

Becker, C. 2007. Amazwi Abesifazane: Voices of Women, in The object of labor: art, cloth, and cultural production, edited by J Livingstone \& J Ploof. Chicago: School of the Art Institute of Chicago Press:113-130.

Botha, A. 2007. Amazwi Abesifazane: Reclaiming the emotional and public self, in The object of labor: Art, cloth, and cultural production, edited by J Livingstone \& J Ploof. Chicago: School of the Art Institute of Chicago Press:131-142.

Christopherson, K. 1995. Appendices: State Quilt Project Data, in Gatherings: America's quilt heritage, edited by KF Sullivan. Paducah, Kentucky: Museum of the American Quilter's Society:212-215.

Du Plessis, M. 2017. Traditional bedding of South Africa's indigenous people. Unpublished manuscript, collection of the author.

Ferrero, P, Hedges, E \& Silber, J. 1987. Hearts and hands: Women, quilts, and American society. Nashville, Tennessee: Rutledge Hill Press.

Gero, A. 2015. Wartime quilts: Appliqués and geometric masterpieces from military fabrics. Roseville, New South Wales, Australia: The Beagle Press. 
Goggin, MD. 2009. Introduction: Threading Women, in Women and the material culture of needlework and textiles, 1750-1950, edited by MD Goggin and BF Tobin. Surrey, England: Ashgate Publishing, Ltd.:1-10.

Gordon, B. 2011. Textiles: The whole story. London: Thames and Hudson, Ltd.

Havenga, W. (bedrock@netactive.co.za). 2020/04/26. E-email to M MacDowell (macdowel@msu.edu). Accessed 1 May, 2020.

Hearn, J, quilt artist. 2013. Interview by author. [Transcript]. 7 September. Johannesburg.

Heunis, V. 2010. Heritage Quilt at the War Museum in Bloemfontein. Stitches ' $n$ Bears:17:20-22.

Hexagon Stars. 1879. South Africa quilt history project. The Quilt Index. [O]. Available: http://www.quiltindex.org/fulldisplay.php?kid=59-9A-11A. Accessed 10 May 2020.

Hlohowskyj, M. 2017. The Colorful, Radical Quilts of Chawne Kimber, Women Arts. [O]. Available: https://www.womenarts.org/2017/02/02/the-colorful-radical-quilts-of-chawnekimber/ Accessed 2 February 2020.

Hunter, C. 2019. Threads of life: A history of the world through the eye of a needle. New York: Abrams Press.

Institute of Museum and Library Services. 2014. Government doubles official estimate: There are 35,000 active museums in the U.S. [O]. Available: https://www.imls.gov/news/government-doubles-official-estimate-there-are35000-active-museums-us.

Accessed 19 May 2020.

Japan Deluxe Tours. 2019. Tokyo the largest quilt show in the world. [O]. Available: https://japandeluxetours.com/experiences/tokyo-quilt-show. Accessed 4 April 2020.

Kimber, C. [Sa]. About. [O]. Available: https://cauchycomplete.wordpress.com/about-2/ Accessed 4 April 2020.

Kirk, M. [Sa]. Heritage quilts, South African quilters' guild. [O]. Available: https://www.quiltsouthafrica.co.za/heritage-quilts Accessed 23 July 2020.

Kriel, S. 2017. The empowering stitch, unpublished manuscript, collection of author. 
Leeb-du Toit, J. 2017. Isishweshwe: A history of the indigenisation of blueprint in Southern Africa. Pietermartzburg: University of KwaZulu-Natal Press.

Livingstone, J \& Ploof, J (eds). 2007. The object of labor: Art, cloth, and cultural production. Chicago: School of the Art Institute of Chicago Press.

Lockhart, PR. 2019. How slavery became America's first big business. [O]. Available: https://www.vox.com/identities/2019/8/16/20806069/slavery-economycapitalism-violence-cotton-edward-baptist.

Accessed 23 July 2020.

MacDowell, M \& Brown, A. 2016. Ubuntutu: Life legacies of love and action. East Lansing, Michigan: Michigan State University Museum.

MacDowell, M \& Dewhurst, CK. 1997. To honor and comfort: Native quilting traditions. Santa Fe, New Mexico: Museum of New Mexico Press.

MacDowell, M \& Dewhurst, M. 2005. Stitching apartheid: Three South African memory cloth artists, in Weavings of war: Fabrics of memory, edited by AZ Cooke \& M MacDowell. East Lansing, Michigan, Michigan State University Museum:77-87.

M. Bimson Quilt. 2016. Collection Document Records. Michigan State University Museum.

McEwan, C. 2003. Building a postcolonial archive? Gender, collective memory and citizenship in post-apartheid South Africa. Journal of Southern African studies 29(3):739-757.

May, R. 2018. The pen and the needle: Intersections of text and textile in and as Nonfiction. Assay: A journal of nonfiction studies 5.1

Miller, K. 2013. Interweaving narratives of art and activism: Sandra Kriel's heroic women, in African art interviews narratives: Bodies of knowledge at work, edited by $\mathrm{J}$ Grabski and C Magee. Bloomington: Indiana University Press:98-113

Mgidi, B, artist. 2011. Interview by author. [Transcript]. 24 February. Johannesburg.

Msibi, C. 2010. Artist statement, Document files, Michigan State University Museum.

Nettleton, A, scholar, University of Johannesburg. 2019. Personal communication with author. 20 November. Johannesburg, South Africa.

Oshins, LT. 1987. Preface, in Quilt collections: A directory for the United States and Canada. Washington, D.C.: Acropolis Books Ltd.:[Sp].

Parker, R. 1984. The subversive stitch: Embroidery and the making of the feminine. London: The Women's Press Limited. 
Pretorius, JC. 1992. Die geskiedenis van volkskuns in Suid-Afrika. Cape Town: Vlaeberg Uitgewers.

Schmahmann, B. 2006. Mapula: Embroidery and empowerment in the winterveld. Johannesburg: David Krut Publishing.

Schreiner, O. 1926 [1982]. From man to man. London: Virago.

Smith, M, quilt artist and quilt owner. 2011. Interview by author. [Transcript]. 16 February. Grahamstown.

South Africa Quilt History Project. 2020. The Quilt Index. [O]. Available: http://www.quiltindex.org/contributor.php?kid=59-C4-0. Accessed 4 April 2020.

The quilting in America 2017 survey. 2017. http://www.quilts.com/news-and-info-qiasurvey.html. ORC International and Advantage Research, Inc. presented by The Quilting Company and Quilts, Inc. Accessed 2 December 2017

Tolksdorf, O, quilt artist. 2011. Interview by author. [Transcript]. 12 February. Durban.

Ulrich, LT. 1990. Of pens and needles: Sources in early American women's history. The journal of American history 77:11.

Vandeyar, D. 2016. Artist statement, in Ubuntutu: Life legacies of love and action, edited by M MacDowell and A Brown. East Lansing, Michigan: Michigan State University Museum: 67.

Walwyn, M. 2016. Boer War quilt, unpublished manuscript. Collection of author.

Webber, M. 2013. Crafting citizens: Material rhetoric, cultural Intermediaries, and the Amawzi Abesifazane South African National Quilt Project. unpublished PhD dissertation, University of Illinois, Urbana-Champaign.

Weiner, A \& Schneider, J. 1989. Cloth and the human experience. Washington, D.C.: Smithsonian Institution Press.

Zegart, S. 1996. The quilt projects: Fifteen years later. Folk Art 21(1):28-37.

Zegart, S \& Holstein, J. 1993. Expanding quilt scholarship: The lectures, conferences, and other presentations of Louisville celebrates the American quilt. Louisville, Kentucky: Kentucky Quilt Project Inc. 